\title{
Anti-diarrheal activity and brine shrimp lethality bioassay of methanolic extract of Cordyline fruticosa (L.) A. Chev. leaves
}

\author{
Sharmin Naher ${ }^{1 *}$, Md. Abdullah Aziz', Mst. Irin Akter², S. M. Mushiur Rahman', Sadiur Rahman Sajon ${ }^{1}$ and \\ Kishor Mazumder ${ }^{1,3}$
}

\begin{abstract}
Background: Cordyline fruticosa (L.) A. Chev. (Asparagaceae) is a plant which is traditionally used for the treatment of cough, bloody cough, diarrhea, dysentery, high fever, difficulties in urine, bloody urine, small pox, madness, skin eruptions, joint pains, rheumatic bone pains, sore throat, neck pain, bleeding hemorrhoids and inflammation in the digestive tract. Therefore, the present work aims to investigate the antidiarrheal and cytotoxic activities of methanolic extract of Cordyline fruticosa leaves in mice and brine shrimp, respectively.

Methods: The effects of the methanol extract of Cordyline fruticosa leaves (MCFL) on castor oil-induced diarrhea, magnesium sulphate induced diarrhea and charcoal meal test in mice were investigated. In addition, brine shrimp lethality bioassay method was used to evaluate cytotoxic activity of MCFL.

Results: In castor oil induced diarrheal test, MCFL at the dose of 200, 400 and $800 \mathrm{mg} / \mathrm{kg}$ body weight significantly $\left({ }^{*} P<0.05\right.$, versus control) and dose-dependently reduced the frequency of diarrhea. The frequency of magnesium sulphate-induced diarrhea was significantly reduced by MCFL at the dose of with $800 \mathrm{mg} / \mathrm{kg}$. In the charcoal meal test, the extract at the dose of 400 and $800 \mathrm{mg} / \mathrm{kg}$ body weight significantly $\left({ }^{*} P<0.05\right)$ reduced the distance travelled by charcoal along the intestinal tract when compare with control. However, in brine shrimp lethality test after $24 \mathrm{~h}$, surviving brine shrimp nauplii were counted and $L C_{50}$ was assessed. The extract exhibited considerable toxicity towards brine shrimp with $\mathrm{LC}_{50}$ value of $355.7 \mu \mathrm{g} / \mathrm{mL}$, with respect to standard vincristine sulfate (having $\mathrm{LC}_{50}$ of $\left.3.8 \mu \mathrm{g} / \mathrm{mL}\right)$.
\end{abstract}

Conclusion: The results of present investigation suggest that methanolic extract of Cordyline fruticosa leaves possesses antidiarrheal and cytotoxic activities, confirming the traditional use of the plant in the treatment of diarrhea.

Keywords: Cordyline fruticosa, Anti-diarrheal, Brine shrimp lethality

\section{Background}

Diarrhea is one of the most common infectious diseases caused by disturbances in secretory and absorptive functions in the intestine, resulting increase in the number (three or more times per Day), flow rate and/or volume of feces $[1,2]$. Shigella flexneri, Staphylococcus aureus, Escherichia coli and Salmonella typhi are the key causative agents of diarrhoea in humans [3]. Populations in

\footnotetext{
*Correspondence: sharmin.snd@gmail.com

${ }^{1}$ Department of Pharmacy, Jessore University of Science and Technology, Jessore-7408, Jessore, Dhaka, Bangladesh

Full list of author information is available at the end of the article
}

socio-economic backwardness, and developing, thirdworld countries, especially infants and children under the age of 5 years are mainly vulnerable to diarrhea [4]. In spite of advancement in public health and economic wealth, diarrhea still remains an important clinical concern in developed countries. The prognosis of diarrhea has been shown to alter by the use of drug such as antimotility drugs (e.g. loperamide hydrochloride, diphenoxylate with atropine, tincture of opium, camphorated tincture of opium, paregoric, codeine), adsorbents (e.g. kaolin, attapulgite, smectite, activated charcoal, cholestyramine), bismuth subsalicylate, racecadotril, quinolones, tinidazole, 
azithromycin and many more but these currently used anti-diarrhoeal drugs are associated with adverse effects like abdominal discomfort, dry mouth, nausea, constipation, addiction, headache, dizziness, epigastric distress, metallic taste, allergic reactions, rashes, fever, eosinophilia and skin eruptions [5]. The World Health Organization (WHO) has introduced a program for the treatment and prevention of diarrheal disease with traditional herbal medicines [3]. Many medicinal plants extract show diarrhea controlling activities with the help of its antispasmodic properties, delay gastrointestinal transit, suppress gut motility, stimulate water adsorption and/or reduce electrolyte secretion [6]. Plants offer medicinal value due to the presence of substances like alkaloids, essential oils, tannins, resins, and many others. These substances act by producing physiological action on the human body. The use of local plants as source of medicine may show some negative effects are mainly as a result of lack of adequate knowledge about safe dosage and presence of noxious by-products in some plants [7]. The toxicity studies of medicinal plants were carried out by using brine shrimp lethality bioassay on the basis of its ability to kill laboratory cultured brine shrimp (Artemia nauplii). The simplicity of technique, commercial availability of inexpensive brine shrimp eggs and low cost make this lethality assay as a useful tool for preliminary toxicity screening of plant extracts, fungal toxins, heavy metals, cyanobacteria toxins, pesticides, cytotoxicity testing of dental material and nanostructures $[8,9]$.

Cordyline fruticosa (L.) A. Chev. (Asparagaceae), commonly known as Ti plant or Palm Lily or Goodluck Plant, consisting of leaves of various colour; red, pink, purplish strips and also with borders of whitish leaves is widely distributed plant in the tropical and subtropical region of the world. Various part of this plant for example root, cortex and leaf use as traditional medicines [10]. The leaves are used as a remedy for the treatment of sore throat, neck pain, bleeding hemorrhoids and to induce abortion. Similarly, the roots are used to get relief from toothache, laryngitis and infections of mammary glands [11].

This medicinal plant is also used for treating cough, bloody cough, diarrhea, dysentery, high fever, difficulties in urine, bloody urine, small pox, madness, skin eruptions, joint pains, rheumatic bone pains and swelling pain due to sprains, kidney diseases, headache and inflammation in the digestive tract. Cordyline fruticosa has been shown to contain cholestane glycosides, polyphenols, flavonoid, glucofructan, tannins, phyto sterols and alkaloids steroidal saponins. Pharmacologically the plant has been reported to impart antioxidant, antibacterial, anti-gastric and cancer activities [10-17].

Therefore, the objective of this study was to investigate the cytotoxic activity in the brine shrimp lethality assay and the anti-diarrheal activity of methanolic extract of Cordyline fruticosa leaves.

\section{Materials and methods Chemicals}

Loperamide hydrochloride was purchased from Square Pharmaceuticals Ltd., Bangladesh and Atropine sulphate was purchased from Gonoshasthaya pharmaceuticals Ltd., Bangladesh. Analytical grade methanol used as solvent which was obtained from Merck, Germany.

\section{Collection and identification of plant material}

Cordyline fruticosa leaves were collected from the village Godkhali, Jhikargacha (at latitude $23.1000^{\circ} \mathrm{N}$ and longitude $89.1333^{\circ}$ E), Jessore, Bangladesh in October, 2017. The identification of leaves was authenticated by the taxonomist Naimur Rhaman, Senior Scientific Officer, National Herbarium of Bangladesh, Dhaka, Bangladesh. A voucher specimen (DACB: 44989), was deposited in the herbarium for future reference.

\section{Preparation of the methanolic extract}

The collected leaves of Cordyline fruticosa were rinsed thoroughly with water to remove dirt. After washing, leaves were shade dried at room temperature for a period of 2 weeks and then dried leaves were ground and sieved to obtain fine powder. These powdered leaves $(500 \mathrm{~g})$ were subjected to extraction with methanol (2.5 L) at room temperature $\left(25 \pm 2{ }^{\circ} \mathrm{C}\right)$ for 14 days with occasional agitation. Therefore, the extract was filtered by passing through cotton followed by Whatman No.1 filter paper and the resultant filtrate was concentrated with the help of rotary evaporator and then air dried. The yield of the dried extract which was obtained from the process was $4.94 \%(w / w)$.

\section{Experimental animals}

Swiss albino mice of either sex (6-7 weeks old), weighing 25-30 g, were used for the experiment which were collected from Jahangirnagar University, Savar, Dhaka, Bangladesh. The animals were maintained under standard environmental conditions, having relative humidity $55 \pm 5 \% \quad 12 \mathrm{~h}$ light $/ 12 \mathrm{~h}$ dark cycle, and temperature $(22 \pm 2)^{\circ} \mathrm{C}$ with $12 \mathrm{~h}$ light-dark for at least 1 week in the animal house for acclimation before experiment. They had free access to food and water ad libitum. The study protocol was approved by the institutional animal ethical committee of Jessore University of Science \& Technology, Jessore, Bangladesh.

\section{Antidiarrheal study Castor oil induced diarrheal test}

The method described by Shoba and Thomas was used for carrying out the test [18]. Before experiment, animals 
were screened for diarrheal test by administering $0.5 \mathrm{~mL}$ of castor oil orally and those animals that started diarrhea were selected finally for the test. After screening, selected twenty five mice were divided into five groups, containing five mice in each group. Mice were fasted for $18 \mathrm{~h}$ with free access to water before experiment. Group 1 was treated with distilled water $(10 \mathrm{~mL} / \mathrm{kg}$ body weight), which served as control; Group 2 received standard drug (Loperamide $3 \mathrm{mg} / \mathrm{kg}$ body weight). Groups 3, 4 and 5 received different doses of the extract $(200,400$ and $800 \mathrm{mg} / \mathrm{kg}$ ) respectively. $30 \mathrm{~min}$ after administration, all mice received $0.5 \mathrm{~mL}$ of castor oil orally to initiate diarrhea and were individually placed in cages on blotting paper. At every hour, the paper was changed. During an observation period of $4 \mathrm{~h}$, the number of diarrheal feces was recorded and the percentage of inhibition of defecation was calculated for every group of animals.

\section{Magnesium sulphate induced diarrheal test}

Magnesium sulphate induced diarrheal test was carried out by following similar procedure as for castor oil induced diarrhea. Prior to the experiment, Preliminary screening of animals for diarrheal test was done by administering magnesium sulphate $(2 \mathrm{~g} / \mathrm{kg}$ body weight) orally. The selected mice were fasted for $16 \mathrm{~h}$ with free access to water. Mice were grouped and treated as described previously. $30 \mathrm{~min}$ later of pretreatments, diarrhea was induced in the mice by oral administration of magnesium sulphate at the dose of $2 \mathrm{~g} / \mathrm{kg}$. The antidiarrheal activity was expressed by comparing the percent of inhibition of defecation of different groups with control group [19].

\section{Effect on charcoal meal test}

The method of Rouf et al. was used for carrying out the test [20]. Mice were fasted for $16 \mathrm{~h}$ with water ad libitum before experiment. They were treated and grouped as mentioned earlier except that atropine sulfate was served as standard drug and administered at a dose of $5 \mathrm{ml} / \mathrm{kg}$ intra-mascularly. All animals of each group received Castor oil $(1 \mathrm{~mL})$ orally and left for one hour after which drug treatment was done. $1 \mathrm{~h}$ later after drug treatments, $1 \mathrm{~mL}$ of charcoal meal (3\% charcoal suspension) was administered to all animals by oral route. After $30 \mathrm{~min}$, all animals were sacrificed. Then, the small intestine was removed and extended on a clean glass surface. The distance moved by the charcoal meal from the pylorus to the caecum was measured and expressed as a percentage of the distance traveled.

\section{Brine shrimp lethality bioassay}

Brine shrimp lethality bioassay method was used to determine cytotoxic activity of Cordyline fruticosa where
Brine shrimps (Artemia salina Leach) nauplii were used as test organisms. For the experiment, $32 \mathrm{mg}$ of test sample was dissolved in dimethyl sulfoxide (DMSO) and solutions of varying concentrations $(800,400,200,100$, $50,25,12.5,6.25 \mathrm{mg} / \mathrm{ml}$ ) were obtained by the serial dilution technique where simulated sea water was used. Then the solutions were added to the pre-marked vials, each containing 10 live brine shrimp nauplii. The volume was adjusted with simulated seawater up to 5 $\mathrm{mL}$ per test tube. Each level of concentration was tested in duplicate. The vials were placed under light for a period of $24 \mathrm{~h}$. $24 \mathrm{~h}$ later, the vials were inspected and the number of survived nauplii in each vial was counted and recorded. In this case, vincristine sulphate was used as a reference standard [21].

\section{Statistical analysis}

All results are expressed as mean \pm standard error of mean (SEM). All statistical analyses were performed by one-way ANOVA followed by Dunnett's $t$-test where ${ }^{*} P<0.05$ was regarded as statistically significant. In addition, all data were analyzed using SPSS software (version 20; IBM Corporation, New York, USA). LC 50 values were calculated by linear regression equations through the usage of Microsoft Excel 2007 (Microsoft, Redmond, Washington, USA).

\section{Results}

\section{Castor oil induced diarrheal test}

In the model of castor oil induced diarrheal test, all dose of MCFL (200, 400 and $800 \mathrm{mg} / \mathrm{kg}$ body weight) significantly (" $P<0.05$, versus control) and dose-dependently reduced the total number of diarrheal feces. The percentage inhibition of diarrhea by the 200, 400 and $800 \mathrm{mg} / \mathrm{kg}$ doses of the extract was determined $56.07 \pm$ $16.06 \%, 60.00 \pm 40.00 \%$ and $85.47 \pm 6.65 \%$, respectively. Significant ( $P<0.05$, versus control) percentage inhibition of diarrhea by loperamide HCL $(5 \mathrm{mg} / \mathrm{kg})$ was $88.45 \pm 5.40 \%$. The results are displayed in Table 1 .

\section{MgSO4 induced diarrheal test}

In the model of $\mathrm{MgSO}_{4}$ induced diarrheal test, loperamide HCL and MCFL produced antidiarrheal effect in mice. MCFL at doses of $800 \mathrm{mg} / \mathrm{kg}$ significantly reduced (" $P<0.05$, versus control) the total number of diarrheal feces and showed highest and significant percentage of inhibition of diarrhea (100.00 $\pm 0.00 \%)$. Administration of loperamide HCL ( $3 \mathrm{mg} / \mathrm{kg}$ body weight), a standard antidiarrheal drug, produced a significant antidiarrheal effect but less than the highest dose of MCFL $(800 \mathrm{mg} / \mathrm{kg}$ body weight).The results are shown in Table 2 . 
Table 1 Effect of MCFL in castor oil-induced diarrheal test

\begin{tabular}{|c|c|c|c|c|}
\hline Group & Dose & $\mathrm{n}$ & Number of diarrheal feces & $\%$ of inhibition of diarrhea \\
\hline Control & $10 \mathrm{~mL} / \mathrm{kg}$ & 5 & $6.00 \pm 0.84$ & $0.00 \pm 0.00$ \\
\hline Loperamide $\mathrm{HCL}$ & $3 \mathrm{mg} / \mathrm{kg}$ & 5 & $0.80 \pm 0.37^{*}$ & $88.45 \pm 5.40^{*}$ \\
\hline MCFL & 200 mg/kg & 5 & $2.80 \pm 0.97^{*}$ & $56.07 \pm 16.06$ \\
\hline MCFL & 400 mg/kg & 5 & $1.20 \pm 1.20^{*}$ & $60.00 \pm 40.00$ \\
\hline MCFL & 800 mg/kg & 5 & $1.00 \pm 0.45^{*}$ & $85.47 \pm 6.65^{*}$ \\
\hline
\end{tabular}

Values are presented as mean \pm standard error. $n=5$ mice in each group. ${ }^{*} P<0.05$, versus control (Dunnett's $t$-test). MCFL methanolic extract of Cordyline fruticosa leaves

\section{Charcoal meal test}

In the model of charcoal meal test atropine sulpfate (5 $\mathrm{mg} / \mathrm{kg}$ ) and MCFL at a dose of 400 and $800 \mathrm{mg} / \mathrm{kg}$ showed significant decrease in the movement of charcoal from pylorus to caecum when compared with control (" $P<0.05$, versus control). In addition, among all the dose of MCFL, higher dose (MCFL $800 \mathrm{mg} / \mathrm{kg}$ ) showed highest and significant \% inhibition (34.87 $\pm 6.82 \%)$ compared with control $\left({ }^{*} P<0.05\right.$, versus control). The results are summarized in Table 3.

\section{Brine shrimp lethality bioassay}

The cytotoxicity activity of methanolic extract of Cordyline fruticosa leaves assayed by the brine shrimp lethality bioassay test. In this assay, at $6.5 \mu \mathrm{g} / \mathrm{mL}$, MCFL showed the lowest $0 \%$ of mortality where, at $800 \mu \mathrm{g} / \mathrm{mL}$, extract showed the highest $85 \%$ of mortality. The results are represented in Table 4.

\section{Discussion}

Diarrhea is usually considered a consequence of increased electrolytes secretion, altered intestinal motility, increased luminal osmolarity and decreased electrolytes absorption [22]. Castor oil induces diarrhea via its active component, recinoleic acid [23]. Liberation of recinoleic acid from castor oil by the action of lipase enzyme induces irritation in the intestinal mucosa, resulting secretion of inflammatory mediators like prostaglandin and nitric oxide, platelet activating factor, cAMP and tachykinins that stimulates intestinal motility with electrolyte and water increase. This effect could occur as a consequence of activating the $G$ protein-coupled prostanoid receptor (EP3) on the smooth muscle cell of the intestine by ricinoleic acid $[3,23]$. The ricinoleic acid readily forms ricinoleate salts with sodium and potassium in the intestine lumen which inhibits sodium-potassium ATPase enzyme and increases the intestinal epithelium permeability, producing a cytotoxic effect on isolated enterocytes. Ricinoleate may increase the influx of extracellular calcium and activate calmodulin dependent secretory mechanism by acting as a calcium ionophore. Castor oil induced secretory diarrhea by activating $\mathrm{Cl}^{-}$channels, causing $\mathrm{Cl}^{-}$efflux from the cell. The efflux of $\mathrm{Cl}^{-}$results in massive secretion of water into the intestinal lumen and profuse watery diarrhoea. Castor oil induced increase in the production of gastric secretion and intraluminal fluid accumulation ensured the involvement of muscarinic receptor effect [5]. It is therefore plausible that the anti-diarrheal action exerted by MCFL may be related to the inhibition of prostaglandin, nitric oxide, platelet activating factor, cAMP and tachykinins synthesis.

$\mathrm{MgSO}_{4}$ induces diarrhea through its osmotic properties preventing the reabsorption of water, leading to an increase in the volume of the intestinal content. After oral ingestion of $\mathrm{MgSO}_{4}$, it promotes the release of cholecystokinin from the duodenal mucosa. This cholecystokinin acts by rising the secretions and motility of small intestine and also inhibiting the reabsorption of sodium chloride and water [24]. Since MCFL showed significant $\left({ }^{*} P<0.05\right.$, versus control $)$ anti-diarrheal activity in magnesium Sulphate induced diarrheal test,

Table 2 Effect of MCFL in $\mathrm{MgSO}_{4}$ induced diarrheal test

\begin{tabular}{|c|c|c|c|c|}
\hline Group & Dose & $\mathrm{n}$ & Number of diarrheal feces & $\%$ of inhibition of diarrhea \\
\hline Control & $10 \mathrm{~mL} / \mathrm{kg}$ & 5 & $9.40 \pm 2.11$ & $0.00 \pm 0.00$ \\
\hline Loperamide $\mathrm{HCL}$ & $3 \mathrm{mg} / \mathrm{kg}$ & 5 & $0.80 \pm 0.37^{*}$ & $91.80 \pm 4.20^{*}$ \\
\hline MCFL & 200 mg/kg & 5 & $7.40 \pm 1.80$ & $13.57 \pm 17.45$ \\
\hline MCFL & 400 mg/kg & 5 & $4.20 \pm 2.08$ & $32.64 \pm 43.08$ \\
\hline MCFL & 800 mg/kg & 5 & $0.00 \pm 0.00 \mu^{*}$ & $100.00 \pm 0.00^{*}$ \\
\hline
\end{tabular}

Values are presented as mean \pm standard error. $n=5$ mice in each group. ${ }^{*} P<0.05$, versus control (Dunnett's $t$-test). MCFL methanolic extract of Cordyline fruticosa leaves 
Table 3 Effect of MCFL on charcoal meal test

\begin{tabular}{|c|c|c|c|c|c|}
\hline Groups & Dose & $\begin{array}{l}\text { Mean length of } \\
\text { intestine }(\mathrm{cm}) \pm \text { SEM }\end{array}$ & $\begin{array}{l}\text { Mean distance traveled by } \\
\text { charcoal meal }(\mathrm{cm}) \pm \text { SEM }\end{array}$ & $\begin{array}{l}\text { Mean\% movement of } \\
\text { charcoal } \pm \text { SEM after } 30 \mathrm{~min}\end{array}$ & $\%$ Inhibition \\
\hline Control & $10 \mathrm{~mL} / \mathrm{kg}$ & $43.60 \pm 1.56$ & $30.40 \pm 1.93$ & $69.74 \pm 3.71$ & $0.00 \pm 0.00$ \\
\hline Atropine sulfate & $5 \mathrm{mg} / \mathrm{kg}$ & $48.20 \pm 2.28$ & $12.74 \pm 3.09^{*}$ & $27.26 \pm 8.12^{*}$ & $58.84 \pm 9.11^{*}$ \\
\hline MCFL & 200 mg/kg & $44.30 \pm 1.65$ & $25.9 \pm 1.41$ & $52.71 \pm 7.03$ & $14.46 \pm 4.59$ \\
\hline MCFL & $400 \mathrm{mg} / \mathrm{kg}$ & $44.80 \pm 2.10$ & $21.5 \pm 2.86^{*}$ & $47.89 \pm 5.66^{*}$ & $26.32 \pm 12.92$ \\
\hline MCFL & $800 \mathrm{mg} / \mathrm{kg}$ & $46.90 \pm 1.98$ & $19.3 \pm 1.40^{*}$ & $40.83 \pm 2.14^{*}$ & $34.87 \pm 6.82^{*}$ \\
\hline
\end{tabular}

$\mathrm{cm}$, centimeter; the values are mean \pm SEM., $n=5 .{ }^{*} P<0.05$ vs control (Dunnett's $t$-test). MCFL Methanolic extract of Cordyline fruticosa leaves

the extract may exert its anti-diarrheal effect by increasing the reabsorption of sodium chloride and water from the gastrointestinal tract and by counteracting the increase in electrolyte secretion.

Gastrointestinal motility test with activated charcoal, usually known as charcoal meal test is carried out to determine the effect of test substance on peristaltic movement. Castor oil hydrolyzed into ricinoleic acid which causes irritation, inflammation of intestinal mucosa and ultimately diarrhea. Inflammation of intestinal mucosa provokes the release of Prostaglandins which stimulate gastrointestinal motility and secrete water and electrolytes [22]. In charcoal meal test, MCFL suppressed the propulsive movement of charcoal meal through the gastrointestinal tract which elucidate that the extract may show its anti-motility effect by inhabiting biosynthesis of prostaglandins.

Anti-diarrhoea activity was found in those plants possessing the presence of phytoconstituents like tannins, alkaloids, saponins, flavonoids, steroids and/or terpenoids [25]. Tannins and flavonoids are thought to be responsible for anti-diarrheal activity by increasing colonic water and electrolyte reabsorption; while others act by inhibiting intestinal motility [5]. It is thus apparent that methanolic extract of Cordyline fruticosa shows

Table 4 Cytotoxic effect of MCFL and positive control vincristine sulphate on brine shrimp nauplii

\begin{tabular}{|c|c|c|c|c|c|}
\hline \multicolumn{3}{|l|}{ Extract } & \multicolumn{3}{|c|}{ Vincristine sulphate } \\
\hline $\begin{array}{l}\text { Concentration } \\
(\mu \mathrm{g} / \mathrm{mL})\end{array}$ & $\begin{array}{l}\% \text { of } \\
\text { mortality }\end{array}$ & $\begin{array}{l}\mathrm{LC}_{50} \\
(\mu \mathrm{g} / \mathrm{mL})\end{array}$ & $\begin{array}{l}\text { Concentration } \\
(\mu \mathrm{g} / \mathrm{mL})\end{array}$ & $\begin{array}{l}\% \text { of } \\
\text { mortality }\end{array}$ & $\begin{array}{l}\mathrm{LC}_{50} \\
(\mu \mathrm{g} / \mathrm{mL})\end{array}$ \\
\hline 6.25 & 0 & & 0.06 & 10 & \\
\hline 12.5 & 15 & & 0.125 & 20 & \\
\hline 25 & 20 & & 0.25 & 25 & \\
\hline 50 & 20 & & 0.5 & 40 & \\
\hline 100 & 25 & 355.7 & 1 & 60 & 3.8 \\
\hline 200 & 55 & & 5 & 80 & \\
\hline 400 & 60 & & 10 & 95 & \\
\hline 800 & 85 & & 20 & 95 & \\
\hline
\end{tabular}

The test of each level of concentration was carried out in duplicate anti-diarrheal effect may be due to the presence of tannins, flavonoids, alkaloids and saponins.

Brine shrimp lethality bioassay has been extensively used for preliminary screening of cytotoxic activity of plant extract. In brine shrimp lethality bioassay, cytotoxic compounds show significant activity and this assay can be recommended as a guide for detection of compounds having anti-tumor and pesticidal activities due to its low cost and simplicity [26].The method of Meyer et al., who classified crude extracts and pure substances into toxic $\left(\mathrm{LC}_{50}\right.$ value $\left.<1000 \mu \mathrm{g} / \mathrm{mL}\right)$ and non-toxic $\left(\mathrm{LC}_{50}\right.$ value $>$ $1000 \mu \mathrm{g} / \mathrm{mL}$ ) [27]. The lethality concentration $50\left(\mathrm{LC}_{50}\right)$ of MCFL was found to be $355.7 \mu \mathrm{g} / \mathrm{mL}$. The inhibitory effect of the extract (MCFL) increased gradually with the increase in the concentration of extract and this effect might be the result of the presence of toxic compounds in the extract which warrants further investigation.

\section{Conclusion}

The anti-diarrheal and cytotoxic activities of Cordyline fruticosa leaves, found in this study, may explain some of the traditional medicinal uses of this plant. The results suggest further studies to isolate and investigate the bioactive compounds and determine the extent of these compounds responsible for the exhibited biological activities.

\section{Abbreviations}

ATPase: Adenosine triphosphatase; CAMP: Cyclic adenosine monophosphate; DMSO: Dimethyl sulfoxide; $\mathrm{LC}_{50}$ : Median lethal concentration;

MCFL: Methanolic extract of Cordyline fruticosa leaves; SEM: Standard error of mean

\section{Acknowledgements}

The authors are grateful to the Department of Pharmacy, Jessore University of Science and Technology, Jessore, Bangladesh for providing facilities to carry out the research work.

\section{Funding}

The study was done through self finance,

\section{Availability of data and materials}

The datasets supporting the conclusions of this article are included within the article. 


\section{Authors' contributions}

Concept - SN; MAA; KM; Design - SN; SMMR; Supervision - MAA; KM; Resources - MAA; MIA; Materials - SN; MIA; SMMR; SRS; Data Collection and/ or Processing -SN; MAA; MIA; SMMR; SRS; Analysis and/or Interpretation SN; MAA; SRS; Literature Search - SN; MIA; SMMR; Writing - SN; MAA; MIA; Critical Reviews - SN; MAA; MIA; SMMR; SRS. All authors read and approved the final manuscript.

\section{Ethics approval}

The study protocol was approved by the institutional animal ethical committee of Jessore University of Science and Technology, Jessore, Bangladesh.

\section{Consent for publication}

Not applicable.

\section{Competing interests}

The authors declare that they have no competing interests.

\section{Publisher's Note}

Springer Nature remains neutral with regard to jurisdictional claims in published maps and institutional affiliations.

\section{Author details}

'Department of Pharmacy, Jessore University of Science and Technology, Jessore-7408, Jessore, Dhaka, Bangladesh. ${ }^{2}$ Department of Pharmacy, Stamford University Bangladesh, 51, Siddeswari Road, Dha, Dhaka ka-1217, Bangladesh. ${ }^{3}$ School of Biomedical Sciences, Charles Sturt University, Wagga Wagga, Australia.

Received: 14 November 2018 Accepted: 21 February 2019

Published online: 01 April 2019

\section{References}

1. Thiago SLA, Douglas SC, Nayara AS, Luan KM, et al. Antidiarrheal activity of cashew GUM, a complex heteropolysaccharide extracted from exudate of Anacardium occidentale L. in rodents. J Ethnopharmacol. 2015:4(174):294-307.

2. Ansaria P, Uddina MJ, Rahman MM, et al. Anti-inflammatory, anti-diarrheal, thrombolytic and cytotoxic activities of an ornamental medicinal plant: Persicaria orientalis. J Basic Clin Physiol Pharmacol. 2017;18(1):51-8

3. Jabri MA, Rtibi K, Ben-Said A, Aouadhi C, Hosni K, Sakly M, Sebai H. Antidiarrhoeal, antimicrobial and antioxidant effects of myrtle berries (Myrtus communis L.) seeds extract. J Pharm Pharmacol. 2016;68(2):264-74.

4. Emmanuel OA, Simeon OK, Kamoru OW, Oyindamola OA. Antidiarrheal activity of Pyrenacantha staudtii Engl. (Iccacinaceae) aqueous leaf extract in rodents. J Ethnopharmacol. 2011;137:148-53.

5. Sarin RV, Narwal S, Bafna PA. Anti-diarrhoeal activity of aqueous extract of Ocimum Kilimandscharicum. J Ethnopharmacol. 2013;148:223-8.

6. Wet HD, Nkwanyana MN, Vuuren SFV. Medicinal plants used for the treatment of diarrhoea in northern Maputaland, KwaZulu-Natal Province, South Africa. J Ethnopharmacol. 2010;130:284-9.

7. Olowa LF, Nuñeza OM. Brine shrimp lethality assay of the ethanolic extracts of three selected species of medicinal plants from lligan city, Philippines. Int Res J Biological Sci. 2013;2(11):74-7.

8. Krishnaraju AV, Rao TVN, Sundararaju D, Vanisreeb M, Tsay HS, Subbaraju GV. Assessment of bioactivity of indian medicinal plants using brine shrimp (Artemia salina) lethality assay. Int J Appl Sci Eng. 2005;3(2):125-34.

9. Krishnaraju AV, Rao TVN, Sundararaju D, Vanisreeb M, Tsay HS, Subbaraju GV. Biological screening of medicinal plants collected from eastern ghats of India using Artemia salina (brine shrimp test). Int. J. Appl. Sci. Eng. 2006:4(2):115-25.

10. Dahlia AA, Ahmad AR, Wahid M. Extraction of color pigment and determination of flavonoid content of andong leaves (Cordyline fruticosa L.) source Makassar city. J Biol Sci Opin. 2013;1(4):294-96.

11. Fouedjoua RT, Teponno RB, Quassinti L. Steroidal saponins from the leaves of Cordyline fruticosa (L.) a. Chev. And their cytotoxic and antimicrobial activity. Phytochem Lett. 2014;7:62-8.

12. Lim TK. Cordyline fruticosa. In: Edible medicinal and non medicinal plants. Dordrecht: Springer; 2015. p. 627-32.

13. Fouedjou RT, Nquelefack-Mbuyo EP, Ponou BK. Antioxidant activities and chemical constituents of extracts from Cordyline fruticosa (L.) a. Chev.
(Agavaceae) and Eriobotrya japonica (Thunb) Lindl, (Rosaceae). Pharmacologia. 2016:7:103-13.

14. Ahmed F, Das PK, Islam MA, Rahman KM, Rahman MM, Selim MST. Antibacterial activity of Cordyline terminalis Kunth. Leaves. J Med Sci (Pak). 2003;3(5):418-22.

15. Liu S, Cao D, Xiao Z, et al. Comparative study of anti-gastric cancer activity between aqueous extract and ethanol extract of folium Cordylines fruticosae. Afr J Tradit Complement Altern Med. 2013;10(4):78-82.

16. Reddy BC, Noor A, Sabareesh V, Vijayalakshmi MA. Preliminary screening of potential flavonoid-subclasses in Myristica fragrans and Cordyline terminalis by LC-ESI-MS. J Pharmacogn Phytochem. 2016;5(6):437-50.

17. Yokosuka A, Suzuki T, Mimaki Y. 2012. New cholestane glycosides from the leaves of Cordyline terminalis. Chem Pharm Bull. 2012;60(2):275-9.

18. Shoba FG, Thomas M. Study of antidiarrhoeal activity of four medicinal plants in castor-oil induced diarrhea. J Ethnopharmacol. 2001;76(1):73-6.

19. Doherty NS. Inhibition of arachidonic acid release as the mechanism by which glucocorticoids inhibit endotoxininduced diarrhoea. Br J Pharmacol. 1981;73(2):549-54

20. Lakshminarayana M, Shivkumar H, Rimaben P, Bhargava VK. Antidiarrhoeal activity of leaf extract of Moringa Oleifera in experimentally induced diarrhea in rats. Int J Phytomed. 2011;3:68-74.

21. Asaduzzaman M, Rana DMS, Hasan SMR, Hossain MM, Das N. Cytotoxic (brine shrimp lethality bioassay) and antioxidant investigation of Barringtonia Acutangula (L). Int J Pharm Sci Res. 2015;6(8):1179-85.

22. Rahman MK, Chowdhury MAU, Islam MT, Chowdhury MA, Uddin ME, Sumi CD. Evaluation of antidiarrheal activity of methanolic extract of Maranta arundinacea Linn. Leaves. Adv Pharmacol Sci. 2015;2015:6 Article ID 257057.

23. Degu A, Engidawork E, Shibeshi W. Evaluation of the anti-diarrheal activity of the leaf extract of Croton macrostachyus Hocsht. Ex Del. (Euphorbiaceae) in mice model. BMC Complement Altern Med. 2016;16:379.

24. Sairam K, Hemalatha S, Kumar A, Srinivasan T, Ganesh J, Shankar M, Venkataraman S. Evaluation of anti-diarrhoeal activity in seed extracts of Mangifera indica. J Ethnopharmacol. 2003;84:11-5.

25. Umer S, Tekewe A, Kebede N. Antidiarrhoeal and antimicrobial activity of Calpurnia aurea leaf extract. BMC Complement Altern Med. 2013;13:21.

26. Ullah MO, Haque M, Urmi KFM, Zulfiker AH, Anita ES, Bbegum M, Hamid K. Anti-bacterial activity and brine shrimp lethality bioassay of methanolic extracts of fourteen different edible vegetables from Bangladesh. Asian Pac J Trop Biomed. 2013;3(1):1-7.

27. Pimenta LPS, Pinto GB, Takahashi JA, Silva LGF, Boaventura MAD. Biological screening of annonaceous Brazilian medicinal plants using Artemia salina (brine shrimp test). Phytomedicine. 2003;10:209-12.

\section{Submit your manuscript to a SpringerOpen ${ }^{\circ}$ journal and benefit from:}

- Convenient online submission

- Rigorous peer review

- Open access: articles freely available online

High visibility within the field

- Retaining the copyright to your article

Submit your next manuscript at $\boldsymbol{\nabla}$ springeropen.com 